\title{
PENINGKATAN PENGETAHUAN ORANGTUA TENTANG PERAWATAN PASCA TRANFUSI PADA ANAK THALASEMIA MELALUI PEMBERIAN KOMUNIKASI INFORMASI EDUKASI BERBASIS AUDIO VISUAL DI KABUPATEN KUNINGAN
}

Nanang Saprudin, Rani Muliany Sudirman

Sekolah Tinggi Ilmu Kesehatan Kuningan Garawagi

ayyumna1985@yahoo.com

\begin{abstract}
Abstrak
Latar Belakang: Insidensi thalasemia pada anak, saat ini terus mengalami peningkatan. Thalasemia yang diderita anak bisa menurunkan kualitas hidup anak baik aspek fisik maupun psikologis. Perawatan pasca tranfusi yang kurang tepat oleh orang tua dipengaruhi oleh faktor pengetahuan. Upaya untuk meningkatkan pengetahuan orang tua dalam perawatan pasca tranfusi bisa dilakukan melalui pemberian komunikasi informasi dan edukasi berbasis audio visual. Tujuan Penelitian: Penelitian ini bertujuan untuk mengetahui perbedaan pengetahuan orang tua dalam perawatan pasca tranfusi pada anak thalasemia sebelum dan sesudah pemberian KIE. Metode: Penelitian ini menggunakan metode kuantitatif dengan quasi eksperimen dengan rancangan nonequivalent control group design dengan menggunakan one group pretest posttest. Subjek penelitian ini adalah orang tua dengan anak thalasemia sesuai kriteria. Teknik pengambilan sampel dengan accidental sampling sejumlah 30 responden. Instrumen yang digunakan menggunakan kuisioner, pemutar video dan LCD. Analisis bivariat yang digunakan adalah uji $t$ dependen. Hasil : penelitian menunjukan ada peningkatan skor dan perbedaan pengetahun responden dengan $\mathrm{p}$ value $0,000<0,05$. Simpulan : terdapat peningkatan rerata skor pengetahuan setelah pemberian KIE dan terdapat perbedaan pengetahuan responden sebelum dan sesudah pemberian KIE. Saran : bagi orang tua untuk menambah informasi menggunakan media elektronik sejenis serta bagi rumah sakit untuk memasukan KIE berbasis audio visual sebagai pengembangan program dalam media penyuluhan khususnya tentang perawatan pasca tranfusi kepada orang tua dengan anak thalassemia.
\end{abstract}

Kata Kunci : KIE, Pengetahuan

\section{Pendahuluan}

Thalasemia merupakan penyakit keturunan akibat adanya kelainan darah. Anak dengan thalasemia ditandai dengan kondisi eritrosit yang mudah rusak atau umurnya lebih pendek dari sel darah normal (120 hari).Berdasarkan hasil penelitian tentang Health Related Quality of Life and Health Utilitiy Values in Beta Thalasemia Major Patients Receiving Different Types of Iron Chelators in Iran menyatakan bahwa pasien thalasemia memiliki banyak keterbatasan dalam kehidupannya. Thalasemia merupakan penyakit kronis yang memerlukan asuhan keperawatan yang kompleks dan waktu relatif lama. Hal ini dikarenakan anak thalasemia juga lebih spesifik dan lebih komplek (Alhamda, 2015).

Hasil penelitian menunjukan bahwa rata - rata skor kualitas hidup anak thalasemia di Thailand sebesar 76,67. Sedangkan penelitian lainnya 
JURNAL ILMU KESEHATAN BHAKTI HUSADA: HEALTH SCIENCES JOURNAL, VOL. 10 NO. 01, JUNI 2019

DOI: https://doi.org/10.34305/jikbh.v10i1.88

menggambarkan skor kualitas hidup anak thalasemia mayor di RS Kariadi Semarang adalah 65,8. Berdasarkan dua penelitian tersebut dapat disimpulkan skor kualitas hidup anak thalasemia di Thailand lebih baik daripada skor kualitas hidup anak thalasemia di Indonesia (RS Kariadi Semarang). Perawatan orang tua pasca transfusi sangat diperlukan untuk mengontrol kondisi anak. Transfusi darah yang diterima oleh anak, akan berdampak pada masalah kesehatan lainnya. Adanya transfusi tersebut selain mengakibatkan penumpukan zat besi dalam tubuh, juga mengakibatkan pembengkakan pada limfa, sehingga perutnya tampak membesar dan terasa sakit. Pada kasus yang lain dapat ditemukan adanya reaksi yang terjadi setelah tranfusi yang ditandai dengan gejala gelisah, lemah, dipsne dan nyeri kepala (Atikah, 2011).

Berdasarkan hasil studi pendahuluan di RSUD 45 Kuningan, ditemukan sebanyak 853 pasien thalasemia yang melakukan kunjungan dan rawat inap. Hasil wawancara diketahui bahwa 6 orang ibu memiliki pengetahuan yang kurang dalam perawatan pasca tranfusi. Oleh karena itu, informasi tentang perawatan pasca tranfusi pada keluarga sangat dibutuhkan dalam membuat keputusan klinis yang tepat.

Penerapan program Komunikasi Informasi dan Edukasi ini diharapkan dapat meningkatkan pemahaman dan pengalaman individu dalam mengambil keputusan serta mengontrol kondisi anaknya, meningkatkan motivasi serta sikap positif ibu dalam memberikan perawatan terhadap anaknya (Azwar, 2011). Hasil penelitian menyarankan agar diberikan penyuluhan kesehatan yang adekuat kepada orang tua sehingga sikap keluarga dalam merawat anak thalasemia akan semakin positif, dengan demikian diharapkan dapat meningkatkan kualitas hidup anak thalasemia.

\section{Metode}

Jenis penelitian yang digunakan yakni penelitian eksperimental. Desain penelitian yang digunakan adalah Quasy Eksperiment Design dengan rancangan one group pre-test dan post-test Design tanpa adanya kelompok kontrol. Populasi dalam penelitian ini adalah semua orang tua yang mempunyai anak thalasemia mayor yang melakukan transfusi di RSUD 45 Kuningan Tahun 2018 sebanyak 119 orang. Teknik pengambilan sampel yang digunakan secara acidental sampling dan memenuhi kriteria. Peneliti membatasi waktu penelitian selama 2 minggu, dimana pada waktu tersebut peneliti mendapatkan 30 responden. Responden yang digunakan sebagai subyek penelitian dibatasi dengan kriteria inklusi, yaitu :

a. Kriteria Inklusi

1) Orang tua yang mempunyai anak thalasemia mayor dan di rawat di poli thalasemia RSUD 45 Kuningan,

2) Bersedia menjadi responden dan menandatangani lembar informed concent,

3) Orang tua yang mempunyai anak thalasemia dan menjalani transfusi $>2$ tahun,

b. Kriteria Eksklusi

1) Orang tua yang tidak mampu baca dan tulis,

2) Orang tua yang anaknya mengalami penurunan kesadaran.

Varibel bebas dalam penelitian ini adalah komunikasi informasi edukasi berbasis audiovisual. Variabel dependen dalam penelitian ini adalah pengetahuan orang tua. Instrumen pada penelitian ini menggunakan kuesioner dan sudah dilakukan uji validitas dimana semua pertanyaan pengetahuan hasilnya valid. Untuk pemberian komunikasi informasi berbasis audiovisual menggunakan SAP dan video. Pengumpulan data yang digunakan dalam penelitian ini mulai dari penyusunan instrumen, uji instrumen dilanjut dengan tahap pelaksanaan penelitian dengan menilai pengetahuan responden sebelum dilakukan intervensi 
serta menilai kembali pengetahuan responden setelah intervensi.

Adapun intervensi yang diberikan berupa komunikasi informasi dan edukasi berbasis audio visual tentang perawatan pasca tranfusi pada anak thalassemia. Hasil uji normalitas data menggunakan uji Saphiro - Wilk menunjukan nilai kelompok sebelum 0,442 dan kelompok setelah $0,06>0,05$ sehingga distribusi data normal. Uji yang digunakan pada penelitian ini menggunakan uji $t$ dependen. Penelitian dilakukan selama 2 minggu kepada 30 responden berdasarkan kriteria. Penelitian dilakukan di ruang anggrek RSUD 45 Kuningan. Penelitian ini tetap memperhatikan etika penelitian.

\section{Hasil}

Berikut ini hasil uji univariat variabel responden yang dijelaskan dalam bentuk tabel berikut:

Tabel 3.1 Pengetahuan Responden Sebelum dan Setelah Diberikan Komunikasi Informasi Berbasis Audio Visual Tentang Perawatan Pasca Tranfusi Pada Anak Thalasemia di RSUD 45 Kuningan

\begin{tabular}{|c|c|c|c|c|c|c|}
\hline No & Kelompok & Mean & Median & Min & Maks & SD \\
\hline 1 & Sebelum & 11,46 & 11,00 & 6 & 17 & 2,94 \\
\hline 2 & Setelah & 14,43 & 14,50 & 10 & 19 & 2,66 \\
\hline
\end{tabular}

Sumber : Hasil pengolahan data (2019)

\begin{abstract}
Berdasarkan tabel 3.1 diketahui bahwa kelompok sebelum diberikan komunikasi informasi edukasi, diperoleh data yaitu nilai mean 11,46 dengan nilai median 11, nilai minimal 6 dan nilai maksimal 17. Adapun nilai standar
\end{abstract}

deviasinya 2,94. Sedangkan bagi kelompok setelah diberikan komunikasi informasi edukasi berbasis audio visual diperoleh data nilai mean 14,43 dengan nilai median 14,5 serta nilai minimal 10 dan nilai maksimal 19. Adapun nilai standar deviasinya 2,66.

Tabel 3.2 Perbedaan Pengetahuan Responden Sebelum dan Setelah Diberikan Komunikasi Informasi Berbasis Audio Visual Tentang Perawatan Pasca Tranfusi Pada Anak Thalasemia di RSUD 45 Kuningan

\begin{tabular}{|c|c|c|c|c|c|c|}
\hline No & Kelompok & Mean & Median & SD & p value & N \\
\hline 1 & Sebelum & 11,46 & 11,00 & 2,94 & 0,000 & 30 \\
\hline 2 & Setelah & 14,43 & 14,50 & 2,66 & & \\
\hline
\end{tabular}

Sumber : Hasil pengolahan data (2019)

Berdasarkan tabel 3.2 diketahui bahwa nilai mean kelompok setelah pemberian komunikasi informasi edukasi berbasis audio visual terdapat peningkatan dibandingkan dengan kelompok sebelum dengan selisih 2,97. Bisa dilihat juga nilai minimal dan nilai maksimal kelompok setelah pemberian komunikasi informasi edukasi berbasis audio visual lebih tinggi daripada kelompok sebelum. Hasil uji statistic diperoleh $\mathrm{p}$ value $=0,000<\mathrm{p}$ $(0,05)$ artinya terdapat perbedaan rerata pengetahuan responden sebelum dan sesudah pemberian komunikasi informasi edukasi berbasis audio visual. Dengan kata lain terdapat pengaruh komunikasi informasi dan edukasi terhadap pengetahuan orang tua tentang pasca perawatan tranfusi pada anak thalassemia.

\section{Pembahasan}

Gambaran Pengetahuan Orang Tua Tentang Perawatan Pasca Tranfusi Pada Anak Thalasemia Sebelum dan Sesudah Diberikan Komunikasi 


\section{Informasi dan Edukasi Berbasis Audiovisual di RSUD 45 Kuningan}

Hasil penelitian diketahui bahwa ada peningkatan skor pengetahuan responden setelah diberikan komunikasi informasi edukasi berbasis audio visual dengan selisih 2,97. Hasil ini juga didukung dimana nilai minimal dan maksimal bagi kelompok yang sudah diberikan KIE umumnya mengalami peningkatan. Komunikasi Informasi Edukasi adalah suatu cara pemberian informasi atau pesan yang berkaitan dengan topik tetentu dari seseorang atau intitusi kepada masyarakat sebagai penerima pesan melalui media tertentu (Fadila, 2014). Peneliti berpendapat hal ini terjadi karena pemahaman orang tua tentang perawatan pasca tranfusi pada anak thalassemia meningkat setelah diberikan komunikasi informasi edukasi berbasis audio visual. Pemberian informasi dengan menggunakan media audio visual ini membantu orang tua untuk menerima informasi secara lebih menarik dan antusias bila dibandingkan dengan metode pemberian informasi konvensional. Adanya visualisasi dari penayangan video tentang materi yang dibahas membuat ketertarikan sendiri bagi responden dimana hal ini dibuktikan dengan banyaknya responden yang bertanya setelah pemberian informasi.

Selain itu, keberhasilan peningkatan pengetahuan responden tidak terlepas dari baiknya pelaksanaan KIE yang dimulai dari tahapan perencanaan mulai dari pemilihan media, penetapan tujuan maupun penyusunan desain. Selain itu, adanya strategi komunikasi yang efektif serta penggunaan bahasa yang logis dan mudah dipahami memberikan nilai tersendiri. Disamping itu, peneliti juga memberikan evaluasi dengan memberikan beberapa pertanyaan soal untuk mengukur kembali sejauhmana pengetahuan responden setelah diberikan informasi. Hal ini sejalan dengan teori yang dikemukakan oleh Notoatmodjo (2010) yang menjelaskan bahwa perluasan informasi yang didapat bisa meningkatkan pengetahuan seseorang. Secara teoritis, pengetahuan orang tua yang baik dalam praktik perawatan anak thalasemia sangatlah diperlukan. Pernyataan ini sesuai dengan fungsi pemeliharaan kesehatan bahwa keluarga mempunyai tugas di bidang kesehatan yang perlu dipahami dan dilakukan salah satunya yaitu memberikan perawatan anggotanya yang sakit atau yang tidak dapat membantu dirinya sendiri (Setiadi, 2008). Dalam hal ini yaitu perawatan orang tua terhadap anak yang menderita thalasemia. Orang tua merupakan orang yang paling dekat dengan anak. Secara teoritis orang tua merupakan orang yang lebih tua atau orang yang dituakan.

Orang tua adalah pusat kehidupan rohani anak, maka setiap reaksi dan emosi anak dan pemikirannya dikemudian adalah hasil dari ajaran orang tuanya. Sehingga, orang tua memegang peranan yang penting dan amat berpengaruh atas pendidikan, serta pemeliharaan kesehatan anak (Wahib, 2015). Menurut Siombo (2010), pengetahuan merupakan kemampuan untuk mengingat beberapa informasi mencakup kegiatan penyuluhan, penyebaran informasi baik secara media cetak atau elektonik berupa video, dan pendidikan formal maupun non formal. Pengetahuan pada hakikatnya merupakan segenap apa yang kita ketahui tentang suatu objek tertentu termasuk di dalamnya ilmu. Hasil penelitian yang dilakukan oleh Wardani (2017), mengatakan bahwa terdapat perbedaan nilai rata-rata pengetahuan siswa sebelum dan setelah diberikan video yaitu mencapai 4.05. Berdasarkan uraian diatas peneliti menyimpulkan bahwa pengetahuan yang baik didapatkan dari perolehan informasi yang jelas dengan menggunakan media tertentu, salah satunya dengan memberikan informasi melalui media audiovisual yaitu video, dalam hal ini yaitu video tentang anak thalasemia dan perawatan anak thalasemia khususnya perawatan pasca transfusi. Penerapan program Komunikasi Informasi dan Edukasi ini diharapkan dapat meningkatkan pemahaman dan pengalaman individu dalam mengambil keputusan serta 
JURNAL ILMU KESEHATAN BHAKTI HUSADA: HEALTH SCIENCES JOURNAL, VOL. 10 NO. 01, JUNI 2019

DOI: https://doi.org/10.34305/jikbh.v10i1.88

mengontrol kondisi anaknya, meningkatkan motivasi serta sikap positif ibu dalam memberikan perawatan terhadap anaknya (Hastuti, 2014).

Perbedaan Pengetahuan Orang Tua Tentang Perawatan Pasca Tranfusi Pada Anak Thalasemia Sebelum dan Sesudah Diberikan Komunikasi Informasi dan Edukasi Berbasis Audiovisual di RSUD 45 Kuningan

Hasil penelitian menunjukkan bahwa setelah diberikan komunikasi informasi dan edukasi berbasis audiovisual rerata responden mengalami peningkatan skor pengetahuan. Berdasarkan uji statistik didapatkan $p$-value $=0,000$ lebih kecil dari $\alpha=0,05$, sehingga dapat diputuskan bahwa $\mathrm{H}_{0}$ ditolak dan Ha diterima artinya terdapat perbedaan pengetahuan orang tua tentang perawatan pasca tranfusi pada anak thalassemia sebelum dan sesudah pemberian komunikasi informasi dan edukasi berbasis audio visual. Pemberian edukasi sangatlah penting dilakukan oleh petugas kesehatan dalam hal ini perawat mengingat perawat merupakan orang terdekat dengan pasien dan keluarga selama menjalani perawatan di rumah sakit. Mengingat salah satu peran perawat sebagai edukator atau pemberi pendidikan kesehatan kepada pasien dan keluarga.

Peran perawat sangat diperlukan, untuk membantu orang tua memahahi penyakit yang diderita anaknya, dan membantu proses perawatan anak selama di rumah. Sebagaimana yang dikemukakan oleh Hidayat (2009) mengatakan bahwa peran perawat sebagai pemberi asuhan keperawatan dapat dilakukan dengan memperhatikan kebutuhan dasar manusia yang dibutuhkan melalui pemberian pelayanan keperawatan dengan menggunakan proses keperawatan. Hal tersebut dilakukan dari yang sederhana sampai dengan kompleks sesuai dengan tingkat kebutuhan dasar manusia. Selain itu, pemberian pendidikan kesehatan terhadap keluarga merupakan salah satu tugas perawat untuk memberikan informasi yang jelas dan benar sesuai peranya sebagai advokat.

Berdasarkan yang terjadi dilapangan, pengetahuan orang tua dipengaruhi oleh beberapa faktor salah satunya yaitu informasi. Dalam penelitian ini, orang tua diberikan informasi tentang thalasemia dan perawatan terhadap anak thalasemia khususnya perawatan pasca transfusi melalui tayangan video. Menurut Widyatuti (2013) mengatakan bahwa penyuluhan dengan menggunakan audio visual lebih menarik dan tidak monoton. Penyuluhan dengan audio visual, menampilkan gerak, gambar, dan suara yang dapat menarik keingintahuan responden terhadap isi video dan melihat video sampai selesai dengan serius.

Hasil penelitian lain ditemukan dalam penelitian yang dilakukan oleh Sulendri (2014), yang berjudul "Penyuluhan dengan Media Audio visual dan Konvensional terhadap Pengetahuan Ibu Anak Balita" diperoleh hasil penelitian terdapat perbedaan rata-rata pengetahuan ibu anak balita (post test) setelah dilakukan penyuluhan audiovisual dan konvensional dengan nilai $p=0,00$. Peneliti berpendapat bahwa pengetahuan seseorang didapatkan dari suatu informasi yang dilihat oleh mata dan didengar oleh telinga yang dapat menambah pengetahuan baru dan membentuk suatu tindakan. Pengetahuan merupakan suatu dasar dari terbentuknya suatu tindakan. Menurut teori WHO yang dikutip oleh Notoatmodjo (2007), salah satu bentuk objek kesehatan dapat dijabarkan oleh pengetahuan yang diperoleh dari pengalaman pribadi. Pengetahuan atau kognitif merupakan domain yang sangat penting untuk terbentuknya tindakan seseorang. Pengetahaun seseorang tentang suatu objek mengandung dua aspek yaitu aspek positif dan aspek negatif.

Berdasarkan hasil penelitian melalui komunikasi informasi dan edukasi berbasis audiovisual tentang thalasemia dan perawatannya, memberikan peningkatan terhadap pengetahuan orang tua, dimana dari 30 responden, 27 diantaranya 
JURNAL ILMU KESEHATAN BHAKTI HUSADA: HEALTH SCIENCES

JOURNAL, VOL. 10 NO. 01, JUNI 2019

DOI: https://doi.org/10.34305/jikbh.v10i1.88

Ciptaan disebarluaskan di bawah

Lisensi Creative Commons Atribusi-

NonKomersial-BerbagiSerupa 4.0

Internasional.

mengalami peningkatan skor pengetahuan. Hal ini sejalan dengan penelitian yang dilakukan oleh Suryani (2013), yang berjudul "Pengaruh Promosi Kesehatan Metode Audiovisual dan Metode Buku Saku terhadap Peningkatan Pengetahuan Penggunaan Monosodium Glutamat (MSG) pada Ibu Rumah Tangga" diperoleh hasil penelitian bahwa terdapat pengaruh promosi kesehatan baik metode audiovisual maupun metode buku saku dengan $\mathrm{p}=0,00$ terhadap peningkatan pengetahuan ibu rumah tangga dalam penggunaan MSG. Hasil penelitian yang dilakukan oleh Bettex (2008) yang berjudul "The Integration of Audio-Scripto-Visual" menyatakan bahwa media audiovisual efektif digunakan sebagai strategi pembelajaran untuk meningkatkan kesadaran atau daya tarik terhadap topik yang disampaikan.

Berdasarkan uraian diatas, dapat disimpulkan bahwa media audiovisual sangat efektif untuk meningkatkan pengetahauan. Hal ini sejalan dengan penelitian yang dilakukan oleh Kapti, (2013) yang mengatakan bahwa media audiovisual efektif untuk meningkatkan pengetahuan dan sikap yaitu $75 \%$ sampai $85 \%$. Hal ini di dukung dengan teori Notoatmodjo (2007) yang mengatakan bahwa salah satu faktor yang mempengaruhi pengetahuan adalah media massa dan informasi. Dalam hal ini media massa yang digunakan adalah media elektronik berupa video yang didalamnya mengandung unsur informasi tentang suatu topik tertentu yaitu thalasemia dan perawatan anak thalasemia.

\section{Simpulan}

Hasil penelitian menunjukan terdapat peningkatan rata - rata skor pengetahuan setelah diberikan komunikasi informasi edukasi berbasis audio visual. Hasil penelitian juga menunjukan terdapat perbedaan pengetahuan orang tua tentang perawatan pasca tranfusi pada anak thalasemia sebelum dan sesudah pemberian komunikasi informasi dan edukasi berbasis audio visual.

\section{Saran}

Bagi orang tua disarankan untuk menambah informasi tentang perawatan pasca tranfusi melalui media elektronik sejenis serta disarankan bagi rumah sakit untuk memfasilitasi ruangan thalasemia menjadi lebih menarik agar anak tidak merasa bosan. Karena kebanyakan yang melakukan transfusi adalah anak-anak. Memasukan metode penyuluhan KIE berbasis audiovisual ini sebagai agenda rutin untuk memberikan informasi kepada keluarga pasien. Disarankan bagi peneliti selanjutnya untuk mengadakan kelompok kontrol, untuk lebih memperkuat hasil penelitian, dan melakukan pengukuran instrumen dengan menggunakan teori memori pada proses pre dan post.

\section{Daftar Pustaka}

Alhamda, dkk. (2015). Buku Ajar Ilmu Kesehatan Masyarakat (IKM). Jakarta : Deepublish

Atikah. (2011). Anemia dan Anemia Kehamilan. Yogyakarta : Nuha Medika

Azwar, S. (2011). Sikap Manusia Teori dan Pengukurannya. Jakarta : Pustaka Pelajar

Bettex. (2008). The Integration of AudioScripto-Visua. Jurnal taylor \& francis group, vol (21). No (2).

Fadila, I. (2014). Efektifitas Penerapan Komunikasi Informasi dan Edukasi terhadap Perilaku Gizi Lansia serta Pos Pelayanan Terpadu (Posbindu) di Tanggerang Selatan. Sripsi Keperawatan Universitas Terbuka: dipublikasikan. Diakses: http//repository.ut.ac.id

Hastuti, P. (2014). Pengaruh Paket Edukasi Thalasemia terhadap Kualitas Hidup Anak Thalasemia. Jurnal Kesehatan, vol (5). No (2).

Hidayat, AA. (2009). Pengantar Konsep Dasar Keperawatan. Jakarta: Salemba Medika 
Kapti, E. (2013). Efektifitas Audiovisual sebagai Media Penyuluhan Kesehatan terhadap Peningkatan Pengetahuan dan Sikap Ibu dalam Tatalaksana Balita dengan Diare di Malang. Jurnal Ilmu Keperawatan, vol 91). No (1).

Khairina. (2013). Gambaran Pendidikan dan Informasi terhadap Pengetahuan Orang Tua tentang Penyakit Thalasemia pada Anak di RSUD dr. Zainuel Abidin Centra Thalasemia Banda Aceh. Tesis Keperawatan : Diterbitkan.

Diakses: http//simtakp.uui.ac.id

Notoatmodjo, Soekidjo. (2007). Pendidikan dan Perilaku Kesehatan. Jakarta : PT Rineka Cipta

Notoatmodjo, Soekidjo. (2010). Metodologi Penelitian Kesehatan. Jakarta : Rineka Cipta.

Setiadi. (2008). Konsep dan Proses Keperawatan Keluarga. Yogyakarta : Graha Ilmu.

Siombo. (2010). Hukum Perikanan Nasional dan Internasional. Jawa Tengah : Gramedia Pustaka Utama.
Sulendri. (2014). Penyuluhan dengan Media Audiovisual dan Konvensional terhadap Pengetahuan Ibu Anak Balita. Jurnal Kesehatan Masyarakat, vol (10) No (1).

Suryani. (2013). Pengaruh Promosi Kesehatan Metode Audiovisual dan Metode Buku Saku terhadap Peningkatan Pengetahuan Penggunaan Monosodium Glutamat (MSG) pada Ibu Rumah Tangga. Jurnal kesehatan masyarakat, vol (7). No (2).

Wahib. 2015. Konsep Orang Tua dalam Membangun Kepribadian Anak. Jurnal Paradigma Institusi, vol (1). No (1).

Widyatuti. (2013). Efektivitas Audiovisual Sebagai Media Penyuluhan Kesehatan terhadap Peningkatan Pengetahuan dan Sikap Ibu dalam Tatalaksana Balita dengan Diare di Dua Rumah Sakit Kota Malang. Jurnal Ilmu Keperawatan, vol (1) No 